\title{
Corporate Legal Liability for Corruption in the Private Sector
}

\author{
Idrus Salam* \\ University of Mubammadiyah Surabaya, Indonesia \\ Satria Unggul Wicaksana Prakasa \\ University of Muhammadiyah Surabaya, Indonesia
}

\begin{abstract}
Corruption in the private sector has been an emerging issue in Indonesia, regarded to become a serious problem to the rule of law. In this case, the problem is the difficulty in tracking down perpetrators of corruption in the private sector since legal accountability does not pay serious attention. For example, the Rolls Royce case involved many jurisdictions in Indonesia that experienced obstacles due to limited authority and low commitment from the country. This study aimed to examine how private sector corruption is linked to legitimizing bribery by foreigners by answering the following questions: what is the legal liability of corporations as perpetrators of corruption in the private sector? What are the legal mechanisms in Indonesia for understanding private sector corruption? In this study, the socio-legal method was used to analyze corruption as a national and international crime to respond to the raised legal issues. The results indicated that the pattern of corruption in the private sector for officials could result in corrupt policies. Furthermore, for the private sector, it can lead to unfair business competition. Therefore, it must be handled immediately so corruption cases in the private sector cannot continue to occur, causing harm to the public and indirectly affecting the country.
\end{abstract}

KEYWORDS: Corruption, Criminal Liability, Private Sector.

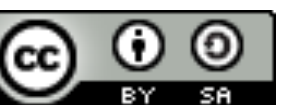

Copyright @ 2021 by Author(s)

This work is licensed under a Creative Commons Attribution-ShareAlike 4.0 International License. All writings published in this journal are personal views of the authors and do not represent the views of this journal and the author's affiliated institutions.

\section{HOW TO CITE:}

Salam, Idrus \& Satria Unggul Wicaksana Prakasa, “Corporate Legal Liability for Corruption in the Private Sector" (2021) 2:2 Indonesian Journal of Law and Society 235-258, online: $<$ https://doi.org/10.19184/ijls.v2i2.24146>.

Submitted: 30/04/2021 Reviewed: 05/05/2021 Revised: 24/09/2021 Accepted: 30/09/2021

\footnotetext{
* Corresponding authors' e-mail: alandhavonar88@gmail.com
} 


\section{INTRODUCTION}

In Indonesia, it is commonly agreed that corruption is an extraordinary crime that involves the government, business agents, and certain people who commit crimes. It relates to the public or specific individuals or groups' interests. Corruption in the private sector is deemed urgent and must be addressed through law and regulations since the Indonesian government's policy of opening investment valves will depend on the extent to which fair business competition practices are conducted. It impacts unfair business competition and has implications for harmful economic growth and investment development. Marbun argued that private sector corruption results in inefficiency, ${ }^{1}$ that undermines market activity by promoting unfair competition and undermining fair competition. ${ }^{2}$ One of the most recent national and international legal instruments important in preventing and eradicating corruption is the validation of the United Nations Convention against Corruption (UNCAC) in 2003.

The Indonesian government took steps to eliminate governance that involves state finances and systematically violates the social and economic rights of the community as a whole. Corporations have become criminals due to rampant corruption involving corporations that are the subject or perpetrators of criminal acts of corruption, under Law 31/1999 and Law 20/2001 on Corruption Eradication. ${ }^{3}$ About 90 percent of corruption cases involve many corporations, either as perpetrators of crimes or parties that provide facilities and infrastructures for criminal acts. ${ }^{4}$ The model is bribery to obtain several national projects or influence policies and unfair business competition. ${ }^{5}$ The fact is that corruption in the private sector is one of the

1 A.N. Marbun, "Suap di Sektor Privat: Dapatkah Dijerat?” (2017) 3:1 J Anti Korupsi Integritas 53-85.

2 Eddy O.S. Hiariej, "Korupsi Di Sektor Swasta Dan Tanggung Jawab Pidana Korporasi” (2020) 49:4 Masal-Masal Huk 333-344.

3 Muridah Isnawati, “Arah Penegakan Hukum Tindak Pidana Korupsi oleh Korporasi dalam Sistem Hukum Pidana Nasional” (2017) 2118.

4 Bambang Widjojanto, "Kajian Awal Melacak Korupsi Politik di Korporasi” (2017) 3:1 J Antikorupsi Integritas 31-52.

5 Ibid. 
most common types of corruption committed in Indonesia. ${ }^{6}$ Meanwhile, Transparency International also released its 25th Corruption Perceptions Index (CPI) for the 2020 measurement year in Indonesia. ${ }^{7}$ CPI 2020 is based on 13 surveys and global evaluations from leading experts and business people to measure public sector corruption in 180 countries and territories. ${ }^{8}$ The CPI evaluation is based on scores. A score of 0 means very corrupt, and a score of 100 is very clean. ${ }^{9}$ Therefore, Indonesia's CPI is less than $2 / 3$ of the countries surveyed and less than 50 points, and the global average score is $43 .{ }^{10}$ Also, in the Asia Pacific, the average CPI score is at 45, down one point from last year's Asia Pacific average of 46 points. Meanwhile, Indonesia CPI 2020 score $37 .{ }^{11}$ It demonstrates a decline in most countries' efforts to eradicate corruption, even in a pandemic situation. ${ }^{12}$ It becomes a concern in the regulation of things that can happen in the private sector.

The corruption pattern in the private sector has weakened and reduced legal and investment problems in Indonesia. One of the fraud cases was committed by the Managing Director of PT Garuda Indonesia from 20052014 Emirsyah Satar and Soetikno Soedarjo as beneficial owners of Connaught International Pte, between 2005 and 2014. ${ }^{13}$ Since there are documents related to the Rolls-Royce case in court, these documents have circulated in the media, so they cannot clearly explain the people involved in the bribery case. The Eradication Corruption Commission officially named Emirsyah Satar, President of Garuda Indonesia from 2005 to 2014, as a suspect in corruption in the procurement of Airbus and Rolls-Royce PLC aircraft and aircraft engines. Commodities worth USD 20 billion and

6 Transparency International, Corruption Perception Index 2020 (Berlin: TI Publisher: 2020).

7 Transparency Internasional Indonesia, "Peluncuran Hasil Indeks Persepsi Korupsi 2020: Korupsi dan Covid-19 Memperburuk Kemunduran Demokrasi” (2021) 1-21.

8 Ibid.

9 Ibid.

10 Ibid.

11 Ibid.

${ }_{12}$ Transparency Internasional Indonesia, supra note 8.

13 Satria Unggul Wicaksana Prakasa, "Garuda Indonesia-Rolls Royce Corruption, Transnational Crime, and Eradication Measures" (2019) 6:3 Lentera Huk 409. 
USD 2 million are found primarily in Singapore and Indonesia. According to the Corruption Eradication Commission, Emirsa was suspected of accepting bribes in this case. From 2005 to 2014, they provided 50 Airbus SAS Aircraft for Garuda Indonesia. ${ }^{14}$ It causes a massive loss to the country's economic situation.

Currently, the scope of corruption is limited to state and business entities' losses whose assets belong to the state or are linked to state finances. Corruption in business transactions in the public sector is on the rise, as is corruption in business groups in the private sector, similar to corruption in business licensing in the forestry department. Various problems arise from the government. Economic donations are not anticipated. Moreover, as the country with $2 \%$ of the world's forest, ${ }^{15}$ Indonesia is experiencing unusual forest degradation. ${ }^{16}$ It becomes the factor contributing to the decline in management expertise in producing round wood, Indonesia's main forest product. In 2008 the number of active ministries reached 71\%. In 2012 this figure had dropped dramatically to only $44 \% .{ }^{17}$ The alleged high pay is inextricably linked to the country's corruption problem. Corruption in the private sector can also have an impact on a country's development. ${ }^{18}$

Corruption currently connects the government and the legislature in procuring goods and services, bribes, and awards. Indonesia's business sector is closely related to bribery and extortion, as defined by bureaucracy and licensing. Furthermore, corruption in the judiciary has exacerbated the situation, making it difficult for institutions to conduct fair and impartial

14 Ibid.

15 In 2010, the total area of Indonesian forest was recorded at 4 billion hectares. Food and Agriculture Organizations of the United Nations, 2020: State of the World's Forest, online: <https://www.fao.org/3/ca8642en/ca8642en.pdf>.

16 Forestry Statistics in 2012, deforestation continued to occur. In 2000-2006, deforestation reached 1,17 million hectares, and between 2006-2009 it reached 0,48 million hectares. Ministry of Environment and Forestry, National Forest Reference Emission Level for Deforestation and Forest Degradation (Jakarta: Directorate General of Climate Change, 2015).

17 Komisi Pemberantasan Korupsi, Titik Rentan Korupsi dalam Perizinan Usaha Sektor Kehutanan (Jakarta: KPK RI, 2013).

18 Ibid. 
trials. ${ }^{19}$ Corruption poses numerous risks to society and individuals and politics, the national economy, and the bureaucracy. Official barriers to eradicating corruption include structural, cultural, instrumental, and managerial barriers. As a result, steps must be taken to address these issues, such as designing and restructuring public services, increasing transparency, monitoring, sanctions, and strengthening anti-corruption support facilities. In Law 31/1999, corruption is classified as harmful to state finances, bribery, public office embezzlement, extortion, fraud, procurement conflicts, and satisfaction. To eradicate corruption, comprehensive law enforcement, international cooperation, and harmonized legislation must be tried. ${ }^{20}$

This research aimed to examine how private sector corruption is linked to legitimizing bribery by foreigners as a form of corruption. Being a country that welcomes foreign investors, the Indonesian people must understand the most effective legal means of preventing companies and determining the jurisdiction and sovereignty of the Indonesian law rule in preventing crime. ${ }^{21}$ Based on the facts stated above, the legal issues raised in this research are into two folds. The first is about the legal liability of corporations as perpetrators of corruption in the private sector. The second is about the legal liability of corporations as victims of corruption in the public sector and the legal mechanisms in place to help people understand corruption in the private sector in Indonesia.

19 Satria Unggul Wicaksana Prakasa, "Social Control Movement as a Corruption Eradication Instrument in Indonesia" (2020) 26:1 Wacana Hukum 21-30.

20 Since the 1960s, several perspectives on how corruption has impacted the economy have emerged. According to popular belief, corruption harms the economy; it is toxic rather than a tonic. However, some believe that corruption can benefit the economy in certain situations, circumstances, and stages. Before 1997, for example, Indonesia and Thailand were countries with rapid economic development despite high levels of corruption. This view was put forward by Nathaniel H. Leff, J.S. Nye, David H. Bayley, dan Samuel Huntington. See Fethi Ben Jomaa Ahmed (2003), "Corruption: A Sociological Interpretative Study with Special Reference to Selected Southeast Asian Case," Ph.D. Thesis, Department of Anthropology and Sociology, Faculty of Arts and Social Sciences, University of Malaya, Kuala Lumpur, at 140-149.

21 Prakasa, supra note 14. 


\section{METHODS}

In this study, socio-legal legal means were used to analyze corruption as a national and international crime. This socio-legal approach is an attempt to investigate further and simultaneously investigate a problem by an insufficient study of related legal norms or doctrines, but also to see the context of norms and their enforcement in full related to the formation of laws to their application. If the general approach method is being used, it will not address the legal issues raised. The goal is to investigate parallel or hierarchical legal rules, particularly anti-corruption, and their relationship to the social control movement. The conceptual approach is the primary focus of legal research, particularly when discussing social control to combat corruption in Indonesia.

\section{CORPORATION AS PERPETRATOR OF CORRUPTION IN THE PRIVATE SECTOR}

In the English-Indonesian Legal Dictionary written by S. Wojowasito, WJS. Poerwadarminta, SAM. Gaastra, JC. Tan (Mich) defines the term corrupt as rotten, not good, lecherous, lecherous, and misprinted. Corruption, which means corruption, rottenness, bribery KKN has become a global problem that must be eradicated and incorporated into a government program to be seriously addressed and suppressed as part of a program to restore people's confidence and the international community to improve the country's economic development. Transparency International shares a definition of corruption as an act of abusing power and public belief for personal wealth. ${ }^{22}$

In this interpretation, there are three factors of the interpretation of corruption, namely: ${ }^{23}$ Abusing or misuse of power; The entrusted power (either in the public or private zone) has business access or the advantage of

22 IGM Nurdjana, Sistem Hukum Pidana dan Bahaya Laten Korupsi, (Yogyakarta: Total Media, 2009) at 14.

${ }^{23}$ Ibid. 
exercising power; Individual benefits, not only always for the individuals who abuse power, but also for their family members and friends.

\section{A. Corruption in the Private Sector}

As a country involved in a variety of international agreements, Indonesia has ratified two significant international treaties, namely the United Nations Transnational Organized Crime (UNTOC) (Indonesia ratified in Law 5/2009) and the United Nations Convention Against Corruption (UNCAC) (Indonesia ratified in Law 7/2006), it is critical to regulating corruption in the private sector. One of the provisions of the UNCAC is that States Parties should combat corruption in the private sector. Article 12 of the UNCAC provides that each state party shall take steps under its basic domestic legal principles to prevent corruption in the private sector, improve accounting and auditing standards, and provide administrative or criminal sanctions for non-compliance with these acts when necessary. Similarly, Article 21 of the Anticorruption Convention strongly advises States Parties to enact laws prohibiting bribery in the private sector. Until now, what UNCAC has proposed has not been translated into legislation ${ }^{24}$ as an international legal instrument that can be used as a weapon for the Indonesian Corruption Eradication Comission or Komisi Pemberantasan Korupsi (KPK), Indonesia's ex-officio of anti-corruption agency or other law enforcers in accommodating transnational corruption-state borders and multi-jurisdictional criminal acts.

Corruption in the private sector is a non-punishable offense. Thus, the states that sign for the convention are not required to include these provisions in their domestic legislation. In general, the provisions of Article 21(1) of the Convention on private sector corruption are: "Any person who leads or works in the private sector promises to give an improper advantage, either directly or indirectly. He or others intend to force the person to do or refrain from doing things contrary to their duties and obligations, which may be detrimental to economic or commercial activities. " Private sector

${ }^{24}$ Prianter Jaya Hairi, "Urgensi pengaturan penanganan tindak pidana korupsi di sektor swasta” (2018) X:24 Info Singk 6. 
corruption occurs both actively and passively in the form of economic loss. Article 21 of the UNCAC requires participating countries to file criminal charges against corruption between companies (private) and governments(public), as well as corruption committed between the two or more companies (private). It delegated the prosecutor's duty and responsibility to file a lawsuit/claim against the private party in court, including that in Indonesia. ${ }^{25}$

Each member country must take measures under its national law's fundamental principles to avoid private sector corruption. They are such as improving accounting and auditing standards in the private sector, and if necessary, imposing effective civil, administrative, or criminal sanctions that compensate for the negligence proportionally. Actions to achieve these goals may include increasing cooperation between the law enforcement agencies and the civil legal entities involved, encouraging the development of standards and procedures designed to protect the integrity of the private legal entities involved, such as correct, respectful, and appropriate precautionary codes of conduct in the conduct of business activities and all related professions, prevent conflicts of interest and increase the application of good commercial practices between businesses and in the contractual relationships of businesses with the state; increasing transparency among private legal entities, including actions involving the identity of legal entities and natural persons involved in the establishment and management of enterprises; and preventing abuse of civil legal entity procedures, including procedures governing subsidies and permits granted by public authorities for commercial activities.

UNCAC criminalizes five actions that are mandatory offenses. They are (a) bribery of national public officials, (b) foreign public officials and officials of public international organizations, (c) embezzlement, misappropriation, or other diversions of property by a public official, (d) laundering of criminal proceedings, and (e) the obstruction of justice. Trading in influence, abuse of function, illicit enrichment, bribery in the private sector, embezzlement of property in the private sector, and concealment are the

25 Prakasa, supra note 14. 
other six actions with non-mandatory offenses. Although it is not the obligation of each participating country to include corruption in the private sector in its national law, this provision must be incorporated into the revision of the anti-corruption law in the Indonesian context. Two provisions in the law on corruption eradication are related to private sector corruption. For starters, private sector bribery can be both active and passive. The second is private sector embezzlement.

\section{B. Corporations as Perpetrators of Corruption}

When it comes to corporate issues, we cannot confine the concept to the realm of civil law. Because the term "company" is closely related to the term "legal entity" (rechstpersoon), and the term "legal entity" itself is closely related to civil law. Setiawan defined rechtspersoon as a legal subject. Despite not being an individual, it has its own set of rights and obligations. It takes the form of an institution or organization made up of a group of people who have come together for a specific purpose and have certain assets. Wirjono Prodjodikoro, on the other hand, stated that a company is a group of people. Typically, the people involved in a company are company members. These members have authority in company regulation and are the supreme members. Members meeting. A tool of power in company regulations. Furthermore, Abidin stated that a corporation is the reality of human associations granted rights under the law, which are granted by legal persons, for specific purposes. ${ }^{26}$

In general, there is no discernible difference in the definition of criminal behavior between dualists and dictators. Those who have committed a criminal act may already have been convicted. In contrast, dualism holds that conviction is not sufficient unless it is accompanied by conditions of criminal liability borne by the one who committed it. A person must be held accountable for his actions under dualism, or that action is held accountable to that person from the perspective of his actions and adheres to the principle of "letting no one wrong in punishment." In this case,

26 Rony Saputra, "Pertanggungjawaban Pidana Korporasi Dalam Tindak Pidana Korupsi” (2018) 15:1 Spektrum Huk at 44. 
dualism contends that even if a person is proven to have committed a criminal act, he cannot be automatically convicted. Instead, it must first be established whether he can be prosecuted criminally against the criminal act he committed. ${ }^{27}$

Article 20 (1) and (2) of the current law state unequivocally that a company or a company representative who has committed a criminal act of corruption may file criminal charges and penalties against the corporation and/or its management. While individuals commit the criminal act with employment or other relationship with the corporation, the corporation commits the crime. Thus, the act is committed individually or collectively within the company environment. This condition is evident at first glance. $^{28}$

The Criminal Code only views people as criminal law subjects, while organizations are not seen as subjects. However, in the turn of additional events, in unique criminal laws, for example, Law Number 7 Drt. 1955 on Investigation, Repression, and Incorrect Financial Equity, Law 31/1999 as revised by Law 20/2001 concerning Amendments to Law 31/1999 on the Elimination of Defamation Violations, Unofficial Law Substitute - Speech 1/2002 on Destruction of Crime of Intimidation as regulated in law based on Law 15/2003 on Specifications of Unofficial Law in Lieu of Law 1/2002 on Eradication of Criminal Demonstrations of Psychological Oppression, as in sectoral laws and regulations and guidelines that contain regulatory penalties, for example, Law 32/2009 on Ecological Safety and The Executors, Law 22/2001 concerning Oil and Natural Gas, Law 41/1999 on Forest Guard Services, Law 4/2009 on Mineral and Coal Mining, and others. Based on the above regulations, companies as valid criminal law subjects. ${ }^{29}$

From a legitimate conventional standpoint, we only see defamation violations in public spaces, specifically, all demonstrations or forms of

Ibid.

${ }^{28}$ Hiariej, supra note 2.

29 Achmad Ratomi, "Korporasi Sebagai Pelaku Tindak Pidana (Suatu Pembaharuan Hukum Pidana Dalam Menghadapi Arus Globalisasi Dan Industri)” (2018) 10:1 J Al'Adl 1-22. 
humiliation defined in Law 31/1999 and Law 20/2001 on Debasement. The focal point of consideration is public authority/government representatives/government employees. ${ }^{30}$ It is impossible to deny that an organization has a distinct personality separate from its investors, leaders, and other company officials. Organizations can manage a property, enter into contracts, sue, and be sued. The owner or investor can respect limited liability; they are either responsible or not for the company's obligations or liabilities. According to the natural hypothetical approach, the original task of the partnership is in the design, arrangement, and authoritative way of life used in the organization. ${ }^{31}$

Regarding the subject of corporate criminal law, the Value Destruction Law is one of the criminal laws that exist outside the Criminal Code. Article 1 of Law 31/1999 on the Destruction of Defamation Violations as amended by Law 20/2001 regarding the correction of Law 31/1999 concerning the Destruction of Defamation states that what is meant by "Everyone" refers to either an individual or a business entity. Article 1 point 1 defines "company" as being managed jointly by people and/or resources coordinated either as legal elements or as illegal materials. It revised Law 3/1971 because it did not include the company as a legal subject. $^{32}$

The Supreme Court provided the Court Guideline 13/2016, which regulates the procedures for handling criminal cases carried out by companies and announced in the State Newspaper 2058/2016 on 29 December 2016. This Guideline is designed to deal with instances of corporate pollution. One of the reasons for issuing the Court Guidelines was that the company's investigation system was not clear as a demonstration of degrading crime to determine whether the company was a criminal demonstration. Article 1 (8) of Court Guidelines 13/2016 explains: "Company misconduct refers to criminal demonstrations for which the partnership may face criminal charges under the Companies Act.

\footnotetext{
${ }^{30}$ Marbun, supra note 1.

31 Rahmi Dwi Sutanti, "Kebijakan Formulasi Tindak Pidana Korupsi di Sektor Swasta" (2016) Research Report, Diponegoro University.

32 Ibid.
} 
This Guideline is in charge of the organization in charge of submitting defamation claims. It acknowledges that this Guideline is insufficient to address the problem of defamation, including corporate defamation, but it can exacerbate the government's arduous tasks in enforcing the law. ${ }^{33}$

Bribery issues that occur in transnational corporations, supplemented by multiple meetings, including public authorities and individual financial managers, can be interpreted as either dynamic (giving/promising earning) or inactive (receiving/asking) direct contributions, including organizations making a profit in business, particularly for organizations around the world looking for a global deal. These exchanges combine the simplicity of authorization from the public authorities of the concerned country or office arrangements in winning business tenders and contracts in countries where these deteriorating practices occur. Deteriorating business practices violate good business administration standards, as communicated in relevant state law and global legal guidelines.

The following comparison can be used to broadly explore corporate acts of corruption/bribery against state officials and fellow business competitors (private entities): ${ }^{34}$

\begin{tabular}{lll}
\hline $\begin{array}{l}\text { Form of } \\
\text { Corruption/Bribery }\end{array}$ & $\begin{array}{l}\text { Origin of Corruption/ } \\
\text { Bribery }\end{array}$ & $\begin{array}{l}\text { Recipient of Corruption/ } \\
\text { Bribery }\end{array}$ \\
\hline $\begin{array}{l}\text { General Office } \\
\text { Corruption or Bribery or } \\
\text { Private Bribery }\end{array}$ & $\begin{array}{l}\text { Company (e.g., Employees, } \\
\text { Subsidiaries, Intermediaries } \\
\text { and Agents, Board of } \\
\text { Directors) }\end{array}$ & $\begin{array}{l}\text { Public officials (Diplomats, } \\
\text { representatives, politicians, and law } \\
\text { enforcement officers from relevant } \\
\text { states) of competing firms, } \\
\text { directors, vendors/opponents }\end{array}$ \\
& & ing
\end{tabular}

Table 1. Concept of Corruption and Transnational Bribery

Muridah Isnawati, supra note 3.

${ }^{34}$ Prakasa, supra note 14. 
Indonesia has Law 30/2002 on the Commission for the Eradication of Defamation as revised by Law 19/2019 as conventional law regarding consent to the KPK. Simultaneously, accepting pollution as a significant legal premise, we can allude to Law 31/1999 concerning the Destruction of Value, revised by Law 20/2001, the same as the related laws and regulations. guidelines in Indonesia. Several types of insults are listed in the Counter Defilement Act. They are rewards, misuse of public assets, extortion, enemies at risk from humiliation arrangements, labor and product contamination, tips, and degradation of useless value for state funds. ${ }^{35}$

On the other hand, the lack of law enforcement through the instrument of Law 11/2018 requires attention. Because private sector bribery is not included in the scope of corruption, the KPK, as an independent state institution dealing with corruption issues, is not authorized to eradicate, prevent, and monitor it. Therefore, under UNCAC recommendations, it is time to include bribery in the private sector in the law as part of a comprehensive effort to eradicate corruption. ${ }^{36}$ Law Number 8 of 2010 concerning Tax Avoidance and Destruction of Tax Avoidance Actors is a type of legislative criminal law problem that forces middle-class criminals to beat them in committing their crimes, mainly when Indonesia is still in a state of financial emergency.

The presence of this law firmly upholds the implementation of the law in maintaining the links between state finances and monetary robustness in criminal law. To avoid and eliminate tax evasion errors, a strong legal entity is required to ensure valid confidence, the sufficiency of legal authorizations, and ongoing recognition and return. Criminal demonstration. When it is done, the perpetrators of the criminal demonstration try to conceal the origin of the resource resulting from the criminal demonstration differently. Consequently, the resource that arises

35 Prakasa, supra note 19.

36 Fariz Cahyana, "Urgensi Pengaturan Suap Di Sektor Swasta Sebagai Tindak Pidana Korupsi Di Indonesia” (2020) 3:1 Jurist-Diction at 61. 
from the offense is complex for legal authorities to follow to use these resources for a legitimate and criminal operation openly. ${ }^{37}$

Article 14 of Law 20/2001 concerning Amendments to Law 31/1999 on the Destruction of Defamation explicitly states that: everyone who violates the legal regulation clearly states that the legal regulation is a criminal demonstration of humiliation managed by this law. The regulation of Article 14 of Law Number Long Term 1999 is possibly expected to become a regulation that can increase the scope of the Defamation Destruction Law to other legal regulations. This regulation is an agreement that the enactment of subsequent regulations will fill in. However, the regulation of Article 14, which is separate from extension development, is also a limitation of the application of the Corruption Eradication Law, so the space of legitimate guidance from lex experts purposefully criticizing lex generalis should be considered towards an extension of the Defamation Destruction Act. Until now, no other legal guideline has specified this law regulation as a criminal demonstration of defamation. ${ }^{38}$ Administrative arrangements for criminal approval are included in the managerial. Understanding criminal law has progressed as a result of lex specialis lessons. Lex Specialis standard no longer only discusses the neglect of the general guidelines (lex generalis) but has also provided a complex and structured criminal law arrangement, arguing that explicit and extra-systematic laws outside the Criminal Code have fallen into disuse. ${ }^{39}$

The Law on Corruption Eradication regulates criminal acts of corruption in Indonesia, regulated under criminal offenses outside the Criminal Code or lex specialis. The Corruption Eradication Law, which regulations are outside the Criminal Code and the Money Laundering Criminal Act, the Banking Act, the Tax Law, is a product of the Administrative Penal Law, which contains conditions governing criminal sanctions. Lex specialis teachings have become increasingly important in understanding criminal

37 Roni Efendi, “Kewenangan Komisi Pemberantas Korupsi Dalam Melakukan Penuntutan Money Laundering” (2018) 17:1 JURIS J Ilm Syariah 117.

38 Ifrani, "Penerapan Undang-Undang Tindak Pidana Korupsi Terhadap Tindak Pidana di Bidang Kehutanan" (2016) 8:2 Al 'Adl at 1.

39 Ibid. 
law. Lex Specialis principle not only discusses the waiver of lex generalis, but it has also provided criminal law solutions of such complexity and form as a result of specific laws and extra codification or that are outside the Criminal Code. ${ }^{40}$

In addition, as a part of the International Anti-Corruption Convention, Indonesia has ratified the UN Convention against Corruption in Law 7/2006. Consequently, Indonesia is obligated to implement and abide by it. Ratification is required to make it a national law and regulate the Indonesian mechanism for dealing with corruption cases. According to the Anti-Corruption Convention, the previous Anti-Corruption Law did not regulate various new corruption crimes, such as foreign bribery, affecting trade, private sector corruption (private sector bribery) to substantial self, getting rich illegally, and so on. ${ }^{41}$ The general public assists the social control cycle through the state without degradation.

According to UNCAC, three flaws will be further investigated. They are impact trade-offs, illegal escalation, and private territory destruction. First, consider the 'Trading in impact' provision in UNCAC in Article 18. The words of Article 18 are as follows when elaborating on their true meaning: "Each Meeting of Nations may consider taking authoritative estimates, and various considerations are essential for determining criminal offenses, each time made on purpose: Guarantees, offers or blessings to public authorities or other individuals, either directly or indirectly, an advantage that cannot be justified in order for the public authority or individual to misuse it or see the impact to obtain from a managerial position or the general population from a State Gathering. The unnecessary benefit to assist the actual demonstration provocateur or for some other individuals. Requests or recognition by public authorities or other individuals, directly or indirectly, of excessive benefits for himself or others so that the public authority or individuals misuse it or see its impacts to obtain excessive benefits from authoritative power or policy management of the Meeting of Nations. ${ }^{42}$

40 Ibid.

41 SUW Prakasa, et al., "Social Aid Of Covid-19 Corruption: Strategy and Mitigation Policy of Muhammadiyah East Java" (2021) 29:1 Leg J Ilm at 27.

${ }^{42}$ Hiariej, supra note 2. 
Second, Illegal Enhancement in UNCAC Article 20 states that subject to the constitution and fundamental standards of law generally, each participating country shall consider adopting authoritative measures and different estimates that may be required to establish as a criminal demonstration, whenever carried out deliberately, illicit enrichment, that is, an enormous increase in public authority resources that cannot be disclosed in a reasonable proportion to their lawful income. Third, regarding debasement in private areas contained in UNCAC, it consists of repayment and abundance diversion in private areas. This is a new regulation for the removal of defilements. Although debasement in the private sphere is an unrequired violation, it must be considered as a criminal demonstration of defamation because it is global and public law, the rules of civitas maxima are under the monism hypothesis, which considers global and public law as a single framework by elevating global law above public law. ${ }^{43}$

\section{CORPORATE LEGAL LIABILITY MECHANISM FOR CORRUPTION}

\section{A. Non-Adjudication}

As stated in Articles 43 to 50 of UNCAC, the goal of state cooperation is for countries where corruptors have escaped to work together to arrest and fire them. It asserts that the country from which corruptors flee has made an ethical commitment not to provide certainty and a different position to the evil one. While the state creates an ideal environment for the corruptors, UNCAC does not administer the legitimate authorizations imposed on the nation but instead relies on the broad standard perceived in international law (general standard of global law). The country involved cannot rely solely on the moral agreements as a refusal from global local areas but must also rely on various supports, for example, monetary prohibition. UNCAC on Article 43 states that the countries involved are required to cooperate on criminal matters where necessary and reliable with their respective common legal instruments. States parties will consider assisting one another with the test and legal procedures on general and

43 Ibid. 
authoritative matters relating to insult. As a consequence, the type of global participation that can be resolved at a time when the resources arising from degrading criminal demonstrations abroad, such as those controlled at UNCAC.

First, extradition is possible by considering the offense committed is remembered for two guilt feelings. ${ }^{44}$ Second, Mutual Legal Assistance. Mutual Legal Assistance (MLA) is a type of collaboration that can put the StAR into effect. In the event of debasement, the presence of MLA is critical in passing the arrival of resources. The MLA tier includes hearings, indictments, and court procedures against complaints, which significantly focus on participation by states, state names, and reciprocal and multilateral companies. MLA's position must also be recognized as one of comprehension and abolition.

Third, Joint investigation. A two-sided or multilateral arrangement should be formed for Joint Investigation. If no arrangements have been made for joint examinations, joint examinations will be conducted by mutual consent, depending on the circumstances. Fourth, law enforcement cooperation. Cooperation between state lawyers (parties) with their separate legal instruments and governments is required to ensure continuity of legal requirements activities in combating violations due to the 2003 UNCAC Show consequences. Collaborative legal authorization can also be defined as a two-sided or multilateral arrangement for coordinating legal authorizing organizations' participation and adapting any arrangements or game plans to exist assumptions. The mutual understanding between the Defilement Annihilation Commission (KPK) and the US Government Customs investigation (FBI) describes the different types of law enforcement cooperation. Fifth, special investigative techniques. Strategies for exceptional analytical methods such as electronic observation or various types of surveillance or covert assignments within its domain and allowing evidence obtained from such exercises to be acknowledged by courts.

44 Abdul Manan Un, "Pembaharuan Hukum Dalam Tindak Pidana Korupsi Pasca Ratifikasi Konvensi Anti Korupsi Tahun 2003”, (2018) 2:2 Maleo Law Journal at 195-221. 


\section{B. Adjudication}

The liability mechanism and the criminal framework are directed in detail, more specifically in criminal demonstrations of defamation committed by or for companies, requests and feelings regarding the partnership and/or its administration can be made. On the other hand, discipline can be prosecuted and terminated if resolved by or for the organization's benefit. Consequently, it is done against "partnerships and chairmen" or against companies. In addition, to acknowledge that the criminal demonstrations are degrading to be carried out by partnerships, this method is carried out by individuals who are reliant on employment relationships and other connections, acting in the professional workplace both independently and in general. ${ }^{45}$

The government reforms the organization to the extent that discipline is enforced collaboratively. Other people may be in charge of the company's administration. Aside from that, the judge can direct the company's administration to appear in front of the court's judgment. The appointed authority can direct the administration that will be brought to court. At that time, the face-to-face summons and its transmission will be forwarded to the administration. Given the addition of one criminal regulation, the only basic discipline that can be postponed against an organization is acceptable.

There are types of corporate disciplines due to various translations in the use of the company as a legal subject. In this regard, there are four examples of feelings towards companies, namely: First, collaborating with the defendant and being charged in court, and discipline ends after administration is first positioned, and discipline is chosen to endure according to law. power (inkracht). Second, the company was named a defendant in court and sued, and the discipline was terminated without prior to the administration's discipline. Third, the criminal verdict on the mysterious public examiner's recording records without being made a

45 Budi Suhariyanto, "Pertanggungjawaban Pidana Korporasi Berdasarkan Corporate Culture Model Dan Implikasinya Bagi Kesejahteraan Masyarakat” (2017) 6:3 J Rechts Vinding Media Pembin Huk Nas at 441. 
defendant. Fourth, organizations are criminalized without being prosecuted and prosecuted by public investigators. ${ }^{46}$

The issuance of the Supreme Court's Guidelines 13/2016 fills the legal void, especially criminal technical law in handling criminal cases with corporate entertainers and leaders. It can be a milestone helping legal experts in criminal management, the case with the entertainer, and the company's head to determine the adequacy and increase in criminal cases handled by entertainment companies and management. To understand the solidarity of understanding, Perma characterizes corporate criminal demonstrations, particularly criminal demonstrations conducted by people who depend on work connections or different connections, either independently or as a whole, or representative persons for the benefit of the organization inside or outside the professional workplace. Perma emphasizes that in committing excessive wrongdoing against a company, the appointed authority can provide a failure assessment as follows: First, partnerships can gain or benefit from criminal demonstrations or criminal demonstrations conducted in support of the organization; Second, the activities that occur are not fraudulent; or Third, the company does nothing to make it safe, preventing a more essential and more certain effect on the relevant legal regulations for avoiding criminal demonstrations.

The three types of corporate misconducts controlled by this Guideline 13/2016 above show the willingness of the High Court to reimpose the corporate criminal risk framework that has not been directed and managed so far. The corporate criminal risk plan accuracy will have far-reaching consequences in the legal requirements system because missteps or deficiencies in this detailed strategy are critical mistakes. It can prevent error avoidance and control at the execution stage, given that the main principle is specialized in adjudicating criminal liability. The company, involving error evidence, has significant work in the early hours to clarify how many public investigators have to show and what the jury needs to

46 Ibid. 
focus on in finding company error during the evidence interaction as the premise of the decision. ${ }^{47}$

In addition, the KPK is an independent state institution in dealing with corruption eradication. According to Law 30/2002 on the Corruption Eradication Commission, the Commission must regulate with an approved organization to eradicate defamation. It should also organize approved offices to destroy insults, complete examinations and indications of defamation, take measures to prevent degrading criminal demonstrations, and screen state organizations. However, the KPK has not agreed to complete the vandalism, anticipation, and payoff demonstrations in private areas because these are not included in the scope of the degrading criminal demonstrations mentioned in the Defamation Law.

\section{CONCLUSION}

The regulation of corruption in the private sector, as stated in UNCAC, is limited to prohibited acts but are not yet a crime because there is no criminal agreement in them. As a state party to the Indonesian AntiCorruption Association of Nations Convention, it is necessary to make strict legal arrangements related to corruption in the private sector, currently under corporate criminal responsibility in Indonesia. The criminal liability of corporations will be directed at investigating criminal law strategies similar to those in different countries to develop a criminal law strategy and justify any deficiencies in criminal law regulations that currently exist in Indonesia regarding the difficulty of tracking down corruption perpetrators from the private sector. The crime of private bribery as a form of corruption in the private sector needs to be regulated in the revision of the Anti-Corruption Law. Consequently, Indonesia should take cooperative action and take legal action against transnational organized corruption crimes. Among the various actions taken between member countries is through Mutual Legal Assistance (MLA). It is a framework for overcoming restrictions, including other cooperative actions, such as extradition, as a legal mechanism that Indonesia can adopt to

47 Ibid. 
request cooperation with other countries related to transnational corruption crimes. Through the bilateral technology agreement mechanism, anticorruption work can be carried out comprehensively, especially in eradicating cross-border corruption according to the recommendations from UNCAC in 2003.

\section{REFERENCES}

Abbas, K.A., The Cancer of Corruption, in Suresh Kohli (ed.), Corruption in India (New Delhi: Chetana Publications, 1975).

Abdul Manan Un, "Pembaharuan Hukum dalam Tindak Pidana Korupsi Pasca Ratifikasi Konvensi Anti Korupsi Tahun 2003” (2018) 2:2 Maleo Law Journal.

Ahmed, Fethi Ben Jomaa, "Corruption: A Sociological Interpretative Study with Special Reference to Selected Southeast Asian Case," Ph.D. Thesis, Department of Anthropology and Sociology, Faculty of Arts and Social Sciences, University of Malaya, Kuala Lumpur (2003).

Cahyana, Fariz, "Urgensi Pengaturan Suap di Sektor Swasta Sebagai Tindak Pidana Korupsi di Indonesia” (2020) 3:1 Jurist-Diction.

Djaja, Ermansjah, Meredesain Pengadilan Tindak Pidana Korupsi (Sinar Grafika: Jakarta, 2010).

Efendi, Roni, "Kewenangan Komisi Pemberantas Korupsi Dalam Melakukan Penuntutan Money Laundering” (2018) 17:1 JURIS J Ilm Syariah.

Food and Agriculture Organizations of the United Nations, 2020: State of The World's Forest, online: <https://www.fao.org/3/ca8642en/ca864 2en.pdf>.

Gunawan, Ilham, Postur Korupsi di Indonesia: Tinjauan Yuridis, Sosiologis, Budaya, dan Politis (Bandung: Angkasa, 1990).

Hairi, Prianter Jaya, "Urgensi pengaturan penanganan tindak pidana korupsi di sektor swasta” (2018) X:24 Info Singk. 
Hamzah, Andi, Pemberantasan Korupsi Melalui Hukum Pidana Nasional dan Internasional (Jakarta : Rajawali Pers, 2008).

Hiariej, Eddy O.S., "Korupsi Di Sektor Swasta Dan Tanggung Jawab Pidana Korporasi” (2020) 49:4 Masal-Masal Huk.

Ifrani, "Penerapan Undang-Undang Tindak Pidana Korupsi Terhadap Tindak Pidana di Bidang Kehutana" (2018) 8:3 Al 'Adl.

Komisi Pemberantasan Korupsi, Titik Rentan Korupsi Dalam Perizinan Usaha Sektor Kehutanan (Jakarta: KPK RI, 2013).

Marbun, A.N., “Suap di Sektor Privat: Dapatkah Dijerat?” (2017) 3:1 J Anti Korupsi Integritas 53-85.

Muridah Isnawati, “Arah Penegakan Hukum Tindak Pidana Korupsi oleh Korporasi dalam Sistem Hukum Pidana Nasional" (2017) 2118.

Nurdjana, IGM, Sistem Hukum Pidana dan Bahaya Laten Korupsi, (Yogyakarta: Total Media, 2009).

Prakasa, SUW, et al., "Social Aid of Covid-19 Corruption: Strategy and Mitigation Policy of Muhammadiyah East Java" (2021) 29:1 Leg J Ilm.

Prakasa, Satria Unggul Wicaksana, "Garuda Indonesia-Rolls Royce Corruption, Transnational Crime, and Eradication Measures" (2019) 6:3 Lentera Huk.

Satria Unggul Wicaksana Prakasa, "Social Control Movement as a Corruption Eradication Instrument in Indonesia" (2020) 26:1 Wacana Hukum 21-30.

Rahmi Dwi Sutanti, "Kebijakan Formulasi Tindak Pidana Korupsi di Sektor Swasta" (2016), Research Report, Diponegoro University.

Ratomi, Achmad, "Korporasi Sebagai Pelaku Tindak Pidana (Suatu Pembaharuan Hukum Pidana dalam Menghadapi Arus Globalisasi dan Industri)" (2018) 10:1 Al 'Adl.

Saputra, Rony, "Pertanggungjawaban Pidana Korporasi Dalam Tindak Pidana Korupsi” (2018) 15:1 Spektrum Huk. 
Singh, Khushwant, “Are We a Corrupt People?”, in Suresh Kohli (ed.), Corruption in India, New Delhi: Chetana Publications, 1975).

Suhariyanto, Budi, "Pertanggungjawaban Pidana Korporasi Berdasarkan Corporate Culture Model dan Implikasinya Bagi Kesejahteraan Masyarakat" (2017) 6:3 J Rechts Vinding Media Pembin Huk Nas.

Transparency Internasional Indonesia, "Peluncuran Hasil Indeks Persepsi Korupsi 2020: Korupsi dan Covid-19 Memperburuk Kemunduran Demokrasi” (2021) 1-21.

Transparency International, Corruption Perception Index 2020 (Berlin: TI Publisher: 2020).

Widjojanto, Bambang, "Kajian Awal Melacak Korupsi Politik di Korporasi” (2017) 3:1 J Antikorupsi Integritas. 
258 | Corporate Legal Liability for Corruption in the Private Sector

This page intentionally left blank 